\title{
Slat armor to protect critical infrastructure
}

\section{INTRODUCTION}

Up until recent years, building a regular fence around the perimeter of critical facilities was considered enough to comply with regulations. Most vulnerability and risk assessments had assumed a low risk of aerial intrusion. Flying objects (either birds, objects carried by wind, or vehicles) were considered to be a lower risk than ground intrusion, therefore, no physical barrier was required to protect the overhead space.

Traditionally, a state which had the capability of conducting an intentional aerial attack was deterred by the risk of an open war, and a high-tech defense system is much more effective than a physical armor. For some facilities, such as military airbases, the risk/reward assessment favours 3 dimensionally reinforced hangars to shelter military aircraft.

In recent years, the world has witnessed a proliferation of Unmanned Aerial Vehicles (UAVs). They are affordable and easy to access, and they are able to carry multiple kilo- grams of explosives for many kilometers and hit a target accurately. These capabilities are now available to individuals who can use them to have access to equipment, installations and material, causing sabotage, damage, or theft. A physical fence against UAVs is an important consideration, as it serves as a last line of defense together with other elements and components.

\section{ABqAiq ATTACK}

In September 2019, the attack on the world's largest oil processing facilities showed the danger of drone intrusion to critical infrastructures. The missile defense system failed to stop the swarm of drones and cruise missiles that struck the oil infrastructure. Figures 1.\&2. show some of the physical damage caused by the attack.

Many unique offensive advantages of drones could be reduced by an overhead slat armor. Although their small size makes drones less visible to radars, it also means a

Figure 1. An aerial photo showing some of the damages on the oil processing facility (Source: Digital Globe)

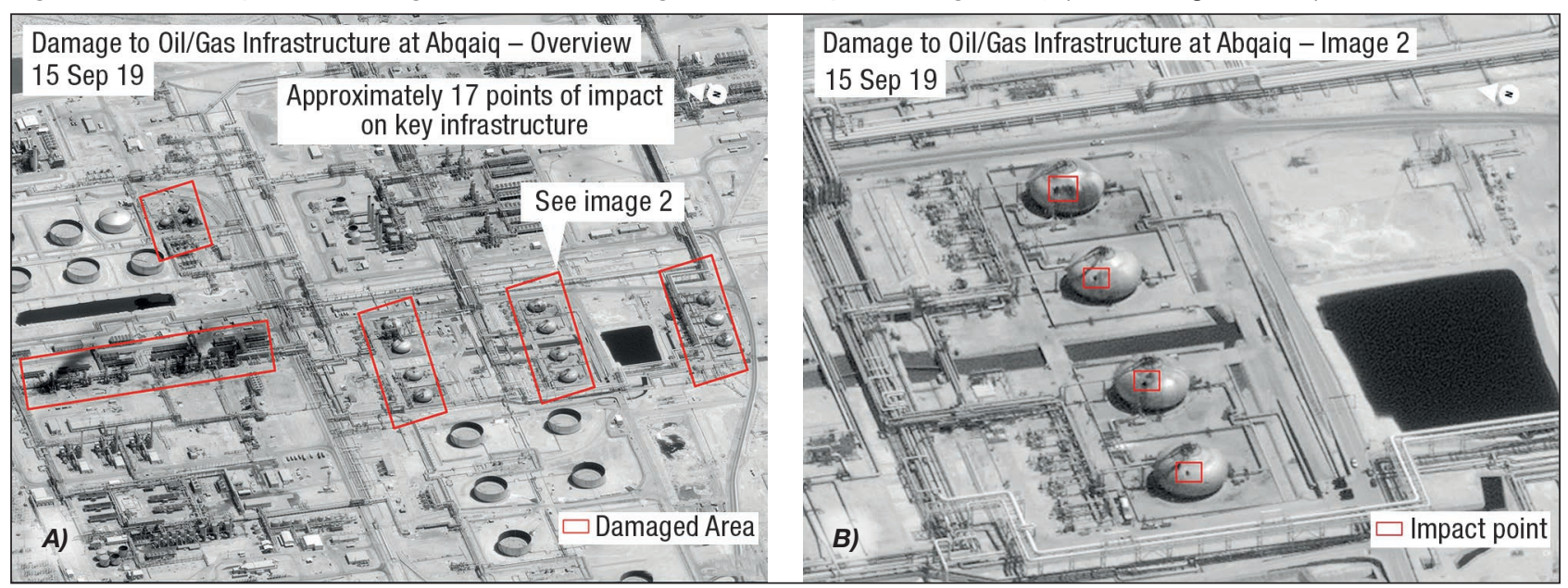

ÖSSZEFOGLALÁS: A külső veszélyek kezelése az egyik legfontosabb prioritás a kritikus infrastruktúra védelme szempontjából. Az ilyen létesítmények védelme állandó alkalmazkodást igényel. A dróntechnika elterjedése új típusú veszélyt jelent, és a drónok olcsók és könnyen hozzáférhetők, tehát hatékony fegyverré válnak, amely a legtöbb létesítmény számára jelentős veszélyt jelent. Tanulmányunkban a felső rácspáncélzat, mint védelmi eszköz használatának jelentőségét tárgyaljuk a légi támadások elleni védekezésben. A tradicionális kerítések csak a földfelszíni védelmet biztosítják, következésképpen egy felső rácspáncélzat használata szükséges a drónok és repülő tárgyak behatolásának megakadályozása érdekében.

KULCSSZAVAK: kritikus infrastruktúra biztonsága, biztonsági kerítés, felső rácspáncélzat, drón behatolás
ABSTRACT: Dealing with external threats has one of the highest priorities when it comes to securing critical infrastructure. The protection of such facilities requires continuous adaptability. The proliferation of drone technology accentuates a new threat, and the low cost and ease of access make it an effective weapon that poses a great danger to most facilities. In this paper, we discuss the need for a slat armor to protect critical infrastructure from aerial objects, as traditional defences provide protection against objects at ground level only. Consequently, an overhead slat armor is necessary to provide adequate defence against flying objects and drone intrusions.

KEY WORDS: critical infrastructure security, protective fence, overhead slat armor, drone intrusion

* Óbuda University, Bánki Donát Faculty of Mechanical and Safety Engineering, Institute of Mechatronics and Vehicle Engineering. Óbudai Egyetem Biztonságtudományi Doktori Iskola. ORCID: 0000-0003-0300-8406 


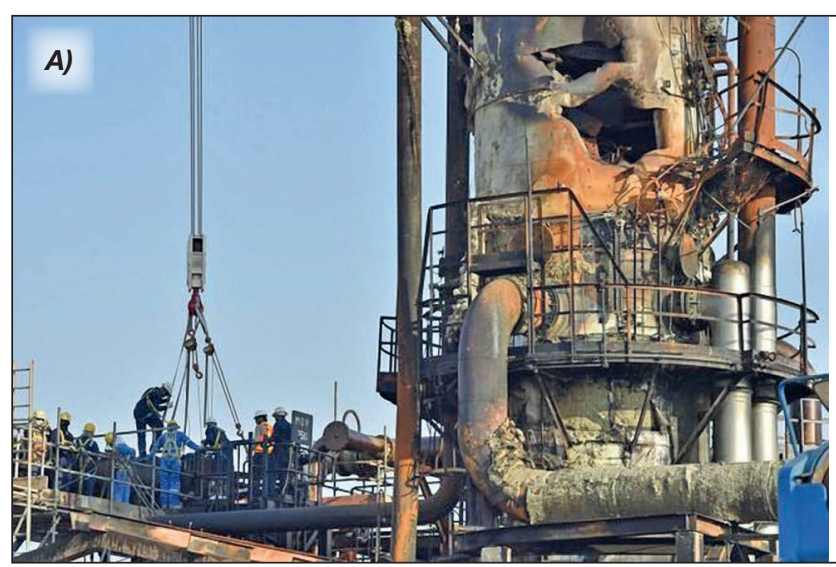

Figure 2. Closer look at the damages

small mass of explosive, and the low flight altitude will result in a smaller kinetic energy impact. Likewise, high manoeuvrability means lower speed, and therefore less kinetic energy impact as well. Similar to the API Std 650 standard published by the American Petroleum Institute (API), European standard EN 14015 code for oil storage tank shell's thickness does not take into the equation any external up-normal impact either, as we can see in the equation used to the outer shell thickness:

$e=\frac{D}{20 S}\left\{98 W\left(H_{c}-0.3\right)+p\right\}+c$

Where: $c$ is the corrosion allowance in millimetres. $D$ is the tank diameter in metres. $e$ is the required thickness in millimetres. $H$ is the distance from the bottom of the shell course. $P$ is the design pressure at the top of the tank in mbar. $S$ is the allowable stress for the appropriate condition in $\mathrm{N} / \mathrm{mm}^{2}$. $W$ is the density of the liquid under consideration in $\mathrm{kg} / \mathrm{l}$.

For the gigantic spherical shaped tanks in Figure 2. we can see that although the impacts have created holes and started a fire, the explosion was not strong enough to destroy the tanks completely.

\section{Fence CRASH TESTING}

Since decades fences have been rated by performing the fence crash test, where different types of vehicles crash into the fence at different speeds. The fences are usually rated based on how far past the fence the vehicle travels in each scenario, as illustrated by Figure 3.

The American Society for Testing and Materials (ASTM) has developed crash certifications for different types of vehicles. They are as follows:

C-ratings: small passenger car (2430 lb.)

Figure 3. Illustration of a crash test for fence rating

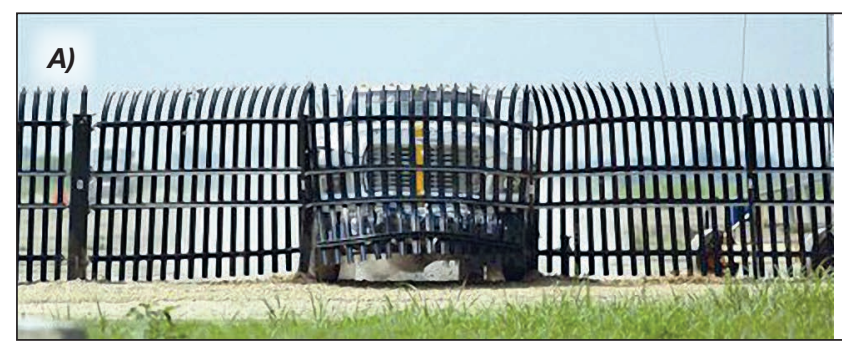

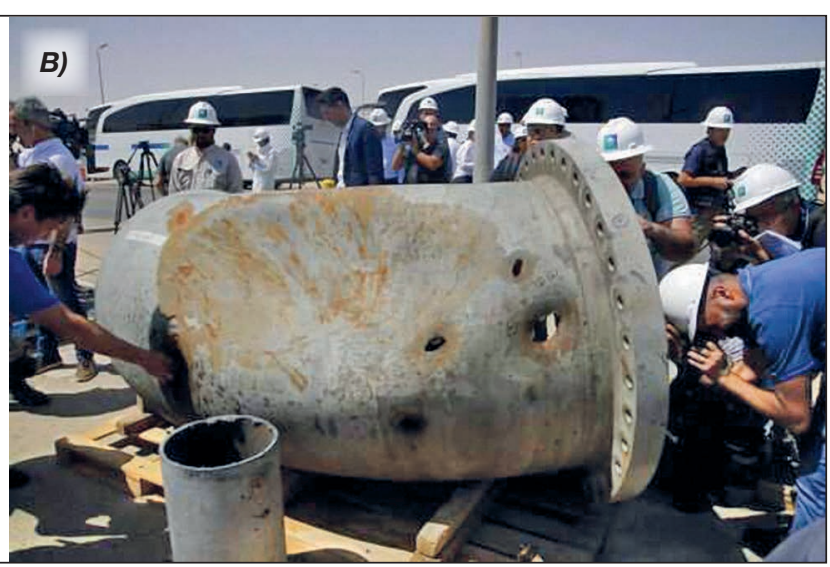

PU-ratings: pickup truck (5070 lb.)

M-ratings: medium-duty truck (15,000 lb.)

$\mathrm{H}$-ratings: heavy goods vehicle $(65,000 \mathrm{lb}$.)

\begin{tabular}{|c|c|c|c|}
\hline $\begin{array}{c}\text { Betafence } \\
\text { anti-ram type }\end{array}$ & $\begin{array}{c}\text { Test } \\
\text { vehicle } \\
\text { weight }\end{array}$ & $\begin{array}{c}\text { Nominat } \\
\text { impact } \\
\text { speed }\end{array}$ & $\begin{array}{c}\text { Penetration } \\
\text { rate }\end{array}$ \\
\hline \multicolumn{4}{|c|}{ American Society for Testing and Materials (ASTM) } \\
\hline M50 P1/P2/P3/P4 & $6800 \mathrm{~kg}$ & $80 \mathrm{~km} / \mathrm{h}$ & $\begin{array}{l}\mathrm{P} 1 \leqq 1 \mathrm{~m} \\
\mathrm{P} 2 \leqq 7 \mathrm{~m} \\
\mathrm{P} 3 \leqq 30 \mathrm{~m} \\
\mathrm{P} 4>30 \mathrm{~m}\end{array}$ \\
\hline M40 P1/P2/P3/P4 & $6800 \mathrm{~kg}$ & $65 \mathrm{~km} / \mathrm{h}$ & $\begin{array}{l}\mathrm{P} 1 \leqq 1 \mathrm{~m} \\
\mathrm{P} 2 \leqq 7 \mathrm{~m} \\
\mathrm{P} 3 \leqq 30 \mathrm{~m} \\
\mathrm{P} 4>30 \mathrm{~m}\end{array}$ \\
\hline M30 P1/P2/P3/P4 & $6800 \mathrm{~kg}$ & $50 \mathrm{~km} / \mathrm{h}$ & $\begin{array}{l}\mathrm{P} 1 \leqq 1 \mathrm{~m} \\
\mathrm{P} 2 \leqq 7 \mathrm{~m} \\
\mathrm{P} 3 \leqq 30 \mathrm{~m} \\
\mathrm{P} 4>30 \mathrm{~m}\end{array}$ \\
\hline
\end{tabular}

A similar rating is suggested to certify different types of slat armors. A similar rating to certify different types of slat armor against aerial objects will help designers and security officials consider the feasibility of integrating the armor into the facility relatively small. The additional costs, weight, and space required will be evaluated based on a vulnerability and risk assessment and on how they can affect the insurance policy of each facility.

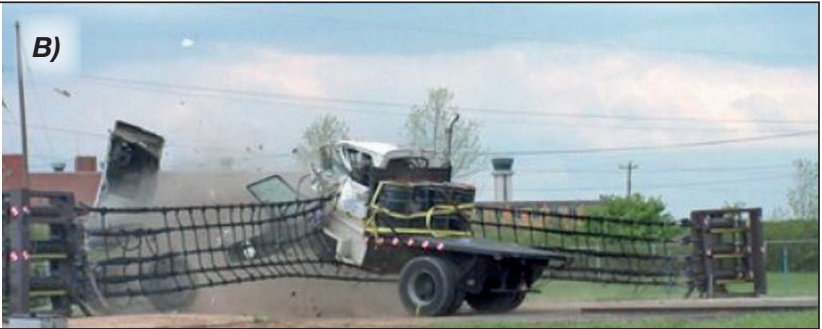




\section{Discussion AND CONCLUSION}

Aerial objects could be classified based on whether the object is loaded with specific weapons (explosives, firearms, chemical... etc.).

Most of the drones that can be acquired by individuals and groups (including the ones used in the Abqaiq attack) weigh less than $150 \mathrm{~kg}$ (nearly half of it a payload), with a maximum speed of $500 \mathrm{~km} / \mathrm{h}$ and a maximum altitude of $4 \mathrm{~km}$, giving them a limited kinetic energy.

Together with other security system elements and components, an overhead slat armor can be very effective to counter this specific threat. The cost, weight, and space of such construction would allow for a multiple layer to stop these drones or detonate the explosives before reaching their targets, thereby reducing the overall impact.

\section{REFERENCES}

[1] API Standard 650 (2007): Welded steel tanks for Oil Storage.11thEdition, American Petroleum Institute.;

[2] API-1164: Pipeline SCADA Security, American Petroleum Institute, API, 2004.;

[3] ARPA, President Obama Announces \$3.4 Billion Investment to Spur Transition to Smart Energy Grid, The White House, Office of the Press Secretary, 2009.;

[4] Jimmy, Dorcas Etim (2014): "Design of a Floating Roof Crude Oil Storage Tank of 100,000BPD Capacities",
Proceedings of the 44th NSChE Annual Conference, Owerri, 2014. Pp. 210-239. ;

[5] T. D. O'RourkE. „Critical Infrastructure, Interdependencies, and Resilience" Engineering for the Threat of Natural Disasters, Vol. 37, No. 1, March 2007, accessed October 2019.,

https://www.nae.edu/19582/Bridge/EngineeringfortheThreatofNaturalDisasters/CriticallnfrastructurelnterdependenciesandResilience.aspx.;

[6] Vaagensmith, Bjorn, Timothy McJunkin, Kurt Vedros, Jesse Reeves, Jason Wayment, Liam Boire, Craig Rieger, and James Case, "An Integrated Approach to Improving Power Grid Reliability: Merging of Probabilistic Risk Assessment with Resilience Metrics," 2018 Resilience Week (RWS), 2018.;

[7] Isabel Coles and Dion Nissenbaum, "U.S.: Saudi Pipeline Attacks Originated from Iraq" and Maher Chmaytelli and Rania El Gamal, "Houthi Drone Attack on Saudi Oilfield Causes Gas Fire, Output Unaffected," August 17, 2019, Reuters https://www.reuters.com/article/us-yemen-saudi-oilattack/houthi-drone-attack-on-saudi-oilfield-causesgas-fireoutput-unaffected-idUSKCN1V705R.;

[8] The official report of "The Fukushima Nuclear Accident Independent Investigation Commission" Executive summary, Published by The National Diet of Japan, The Fukushima Nuclear Accident Independent Investigation Commission, (C) 2012, The National Diet of Japan.

\section{Szabó Miklós}

\section{Airbus A300B és A310 típuscsaládok}

Az Airbus A300B és A310 típuscsaládok című kötet 2019-ben jelent meg az Aposztróf Kiadó gondozásában. A kereskedelmi repülőgépeket bemutató könyvsorozat második kötetével Szabó Miklós visszatér a közös európai repülőgépgyártás kezdeteihez, az Airbus repülögépgyár történetéhez. A kötetben - a gyártás kronológiai sorrendjében - önálló fejezetek foglalkoznak az egyes típuscsaládokokkal. A szerző, Szabó Miklós rendőr alezredes, évekig nemzetközi repülésbiztonsági összekötő tisztként dolgozott. Széles látókörű, kiváló szakemberként, ugyanakkor a polgári repülés szerelmeseként kalauzolja az olvasót.

A kötet megismerteti az érdeklődőket a fejlesztésben együttműködő négy európai ország (Egyesült Királyság, Franciaország, Német Szövetségi Köztársaság és Spanyolország) megállapodásaival. Az olvasó végig követheti az első Airbus A300B gyártási mozzanatait, a hangárból való kigördülését és a tesztrepüléseit is. (A prototípus 1972. október 28-án hajtotta végre felszállását és 1974. május 30-án állt szolgálatba). A szerző bemutatja a polgári repüléstörténet első kétpilótás, szélestörzsű repülőgépét, majd megismerhetjük az A300B repülőgépek, valamint a csökkentett utaslétszámú, ugyanakkor közepes- és nagy hatótávolságú utód, az A310-es történetét. Önálló fejezet szól a típuscsalád gyártásának fejlődéséről is, amelynek főszereplője az A300B4-600-as típus alapjaira felépített különleges szállítógép, a Beluga. A könyvben áttekinthetjük a forradalmian új megoldásokat tartalmazó repülési integrált adatrendszer technológiai újdonságait. Ezt a megoldást elsőként az A310-300-as család gépeiben alkalmazták. A szerző megemlékezik az Airbus neves tervezőiről, valamint azokról az újítókról, akik megálmodták és megszervezték Európa közös kereskedelmi repülőgépgyártásának rendszerét.

Szabó Miklós ismeretterjesztő stílusban, részletesen mutatja be a különböző típusvariánsokat, azok műszaki sajátosságait és specialitásait. Az érdeklődésre számottartó kézikönyvet számos fotó, háromnézeti rajz és a műszaki paramétereket összefoglaló táblázat illusztrálja. Az adatgazdag kötetet a repüléstörténet iránt érdeklődő olvasóknak, valamint - a szerzőt idézve - „minden repülésbarátnak” ajánljuk.

A cérnafüzött, keménytáblás, 174 oldal terjedelmű könyv 3900 Ft-os áron kapható a könyvesboltokban, illetve megrendelhető az Aposztróf Kiadó honlapján, a https://www.aposztrof.hu/component/virtuemart/ utazás?ltemid=101 címen, 23\%-os kedvezménnyel. (W. T.) 